\title{
COMPARATIVE ANALYSIS OF HEMP FIBER GROWN IN YEAR $2010^{\mathrm{TH}}$
}

\author{
Liga Freivalde, Silvija Kukle, Vita Puplakse, Brigita Purina \\ Riga Technical University, Department of Design and Textile Products Technology \\ Azenes St14/24, Riga, LV 1048, Latvia \\ Ph.: +(371 ) 67089816, fax: +(371) 67089816, e-mail: sv85@inbox.lv
}

\begin{abstract}
Annually increasingly all over the world is observed growing tendency to reduce the production of various products containing non-renewable component and replace them with natural fiber raw materials for textile and non-textile products as well. One of such raw materials is hemp. This paper discusses comparative study results of testing local genotype „Purini“ and commercial available ES registered industrial hemp variety „Bialobrzeskie” (Poland) fibers which were grown in Latvia, year 2010 ${ }^{\text {th }}$. Studies have been carried out for small fiber bundles to determine the durability properties of hemp fiber.
\end{abstract}

Keywords: hemp fibres, distribution, durability cycles, hemp variety, hemp line.

\section{Introduction}

Hemp is classified as environmentally friendly natural fiber in processes of cultivation, processing, hemp products exploitation and liquidation. Hemp production easily biodegradable and disposable requires relatively little fertilizer in comparison with other fiber crops, and, having few natural predators, it needs little or no treatment with pesticides [1]. Throughout the life cycle of hemp cultivation, processing and consumption of technical products and the elimination in the end of life-cycle, energy consumption is lower than the others, particularly on petroleum-based fibers designed products. Hemp benefits the environment and the rural economy while providing a sustainable alternative source of fiber for paper, textiles, nonwovens and other purposes. With few insect enemies and little competition from weeds, hemp is good candidate to produce a high-quality, sustainable grown fiber for using in manufacturing of nonwoven products as well as other materials. Hemp also is vital to maintaining air by removing carbon dioxide and returning oxygen [1;2].

In Latvia fiber hemp areas for industrial uses have been started only since year 2008 in following volumes: 5 ha in year 2008, 140 ha in year 2009 and 72 ha in year 2010 [3].

In order to move forward successfully is need to solve a range of issues related to hemp growing agro-technical problems, pretreatment, processing, use of field selection/ expansion, advanced, cost-effective technologies at all stages of development, as well as appropriate methodologies for properties testing of raw materials for intermediates and final product specifications development.

In many applications of products obtained from hemp fiber which are subjected to cyclical deformations in processing and use of processes, which over time leads to the exercise of a function of withdrawal - which shortens the product life cycle, usage efficiency.

Riga Technical University current studies of hemp fiber physical and mechanical properties testing methodology approbation and development $[4 ; 5 ; 6 ; 7 ; 8]$ directed towards full spectrum of properties exploration, the effective selection of test parameters in order to make the testing process less time consuming, but at the same time provide adequate exploitation properties prediction.

\section{Materials and methods}

Object of investigation. Hemp fibers used in this study were obtained from hemp stems harvested from a trial plot at Agriculture Science Centre of Latgale - local dioeciously variety 
"Purini” and ES registered monoecious industrial hemp variety „Bialobrzeskie” in Vilani district, Latvia. In order to extract fibres from retted „Bialobrzeskie” hemp stems slightly modified flax scutching line was used. Hemp fibers in growing process were cultivated with active nitrogen fertilizer doses by looking at 2 options: 1 ) with no additional fertilizer (N0), 2) with active nitrogen $100 \mathrm{~kg} / \mathrm{ha}(\mathrm{N} 100)$.

Methods. Durability tests for small fiber bundles of genotypes „Purini“ and „Bialobrzeskie” were carried out on pulsator UB-5 [7, figure 1] till samples full degradation with frequency $250 \mathrm{~min}^{-1}$. Small fiber bundles for experiments were obtained by mechanical separation. Under microscope were selected $0,04 \mathrm{~mm}$ thin fiber bundles and pasted into the millimeter paper with the fibres clamping length $20 \mathrm{~mm}$ [7, figure 1]. Total amount of made and tested samples: a) variety "Purini" - 100 samples with no additional fertilizer (PN0), b) variety "Purini" - 100 samples with active nitrogen $100 \mathrm{~kg} / \mathrm{ha}$ (PN100) and c) variety „Bialobrzeskie” - 100 samples with no additional fertilizer (BN0). All samples were tested under the same circumstances - with amplitude 0,25 $\mathrm{mm}$ and load 0,7 grams.

For the treatment of the results used descriptive methods of mathematical statistics statistical basic values (Average, Mode, Median, Standard Deviation, Maximum, Range, Standard Error, Confidence Level, Relative error, Kurtosis, Skewness), distriburion analysis.

\section{Results and discussion}

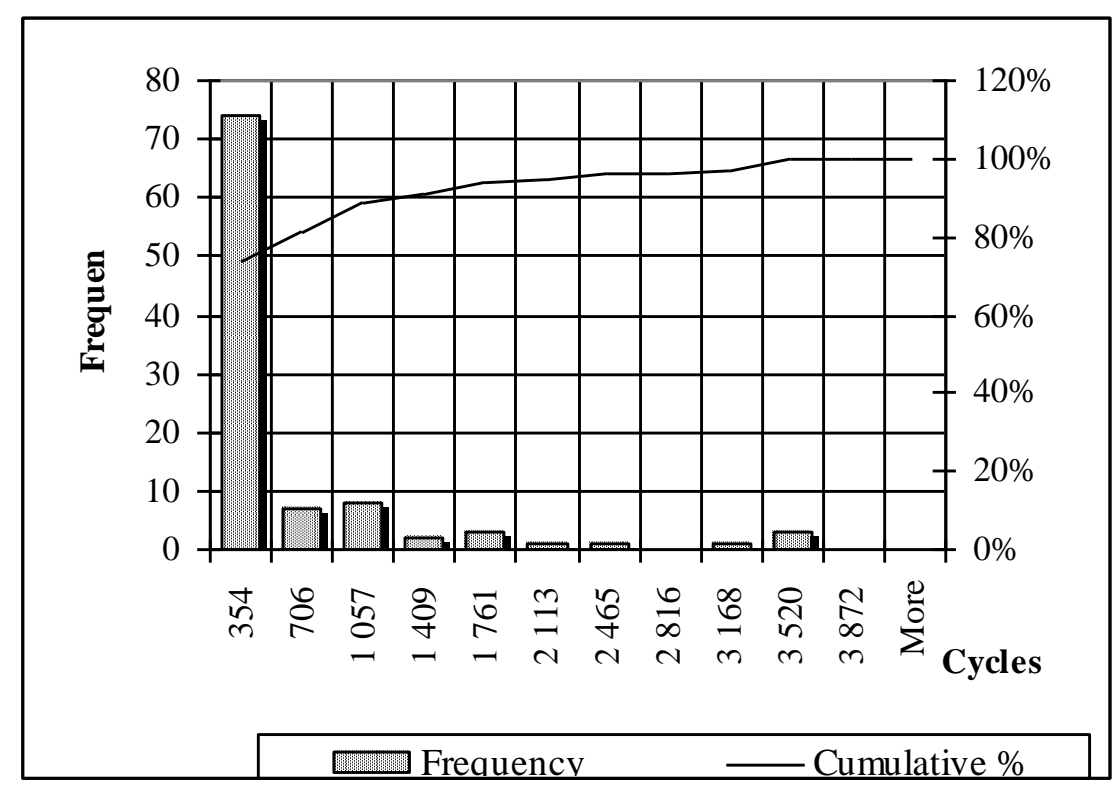

Fig.1. Histogram of cycles till breaking (sample PN0)

As seen from graph (Fig.1) almost $80 \%$ of samples durability does not exceed 354 cycles. Histograms of other two experimental ranges (PN100 and BN0) show similar assimetry.

For methodology development descriptive statistics parameters are calculated including all measurements (table 1). As examination of histograms shows that only a few measurements exceed 2000 cycles, the same statistic parameters are calculated under durability mesurements if experiment become interupted after 2000 cycles (Table 2).

From graphs of Fig. 1 are seen that average values for variants PNO and BNO become lower as influence of few large values removed. But confidence level of these two variants become lower too. Measurements of variant PN100 do not include extrem high cycle values and as a result average and confidence level is the same in both cases (Fig.1). 
Table 1.

Main statistic parameters of samples under examination till full degradation

\begin{tabular}{|c|c|c|c|}
\hline & P N100 & P N0 & B N0 \\
\hline Average & 123,83 & 396,38 & 271,78 \\
\hline Mode & 2 & 2 & 20 \\
\hline Median & 20 & 70 & 30 \\
\hline Standard Deviation & 305 & 738 & 756 \\
\hline Maximum & 1990 & 3520 & 5320 \\
\hline Minimum & 2 & 2 & 1 \\
\hline Range & 1988 & 3518 & 5319 \\
\hline Standard Error & 30,48 & 73,78 & 75,63 \\
\hline Confidence Level (95,0\%) & 59,75 & 144,61 & 148,24 \\
\hline Relative error & $48 \%$ & $36 \%$ & $55 \%$ \\
\hline Kurtosis & 20,00 & 7,57 & 29,19 \\
\hline Skewness & 4,21 & 2,72 & 5,12 \\
\hline
\end{tabular}

Table 2.

Main statistic parameters of samples under examination till 2000 cycles $<2000$ cycles

\begin{tabular}{|c|c|c|c|}
\hline & P N100 & P N0 & B N0 \\
\hline Average & 123,83 & 344,88 & 211,18 \\
\hline Mode & 2 & 2 & 20 \\
\hline Median & 20 & 70 & 30 \\
\hline Standard Deviation & 305 & 557 & 427 \\
\hline Maximum & 1990 & 2000 & 2000 \\
\hline Minimum & 2 & 2 & 1 \\
\hline Range & 1988 & 1998 & 1999 \\
\hline Standard Error & 30,48 & 55,67 & 42,73 \\
\hline Confidence Level(95,0\%) & 59,75 & 109,11 & 83,75 \\
\hline Relative error & $48 \%$ & $32 \%$ & $40 \%$ \\
\hline Kurtosis & 20,00 & 2,58 & 8,89 \\
\hline Skewness & 4,21 & 1,89 & 2,99 \\
\hline
\end{tabular}




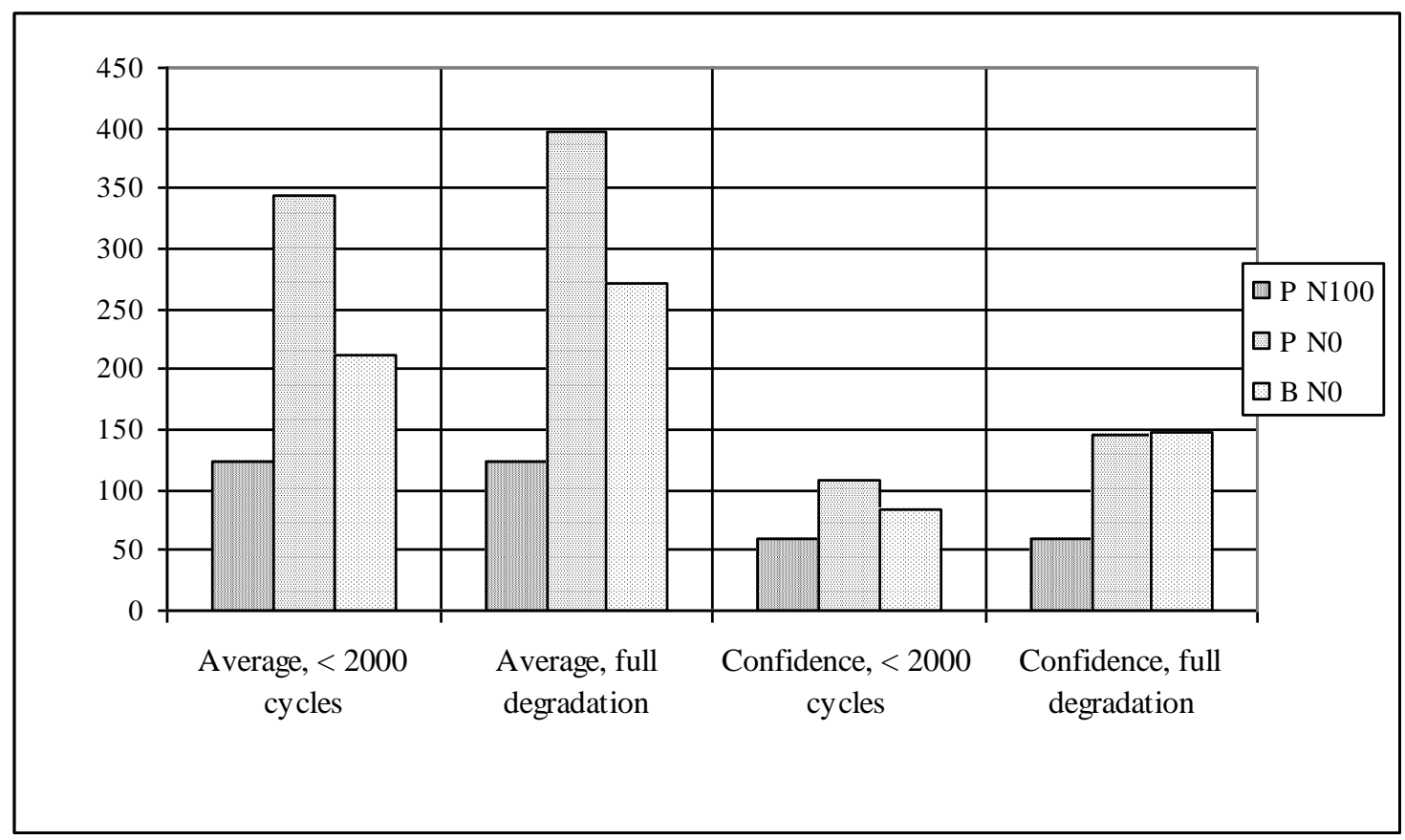

Fig. 2. Average values of durability cycles and corresponding confidence intervals

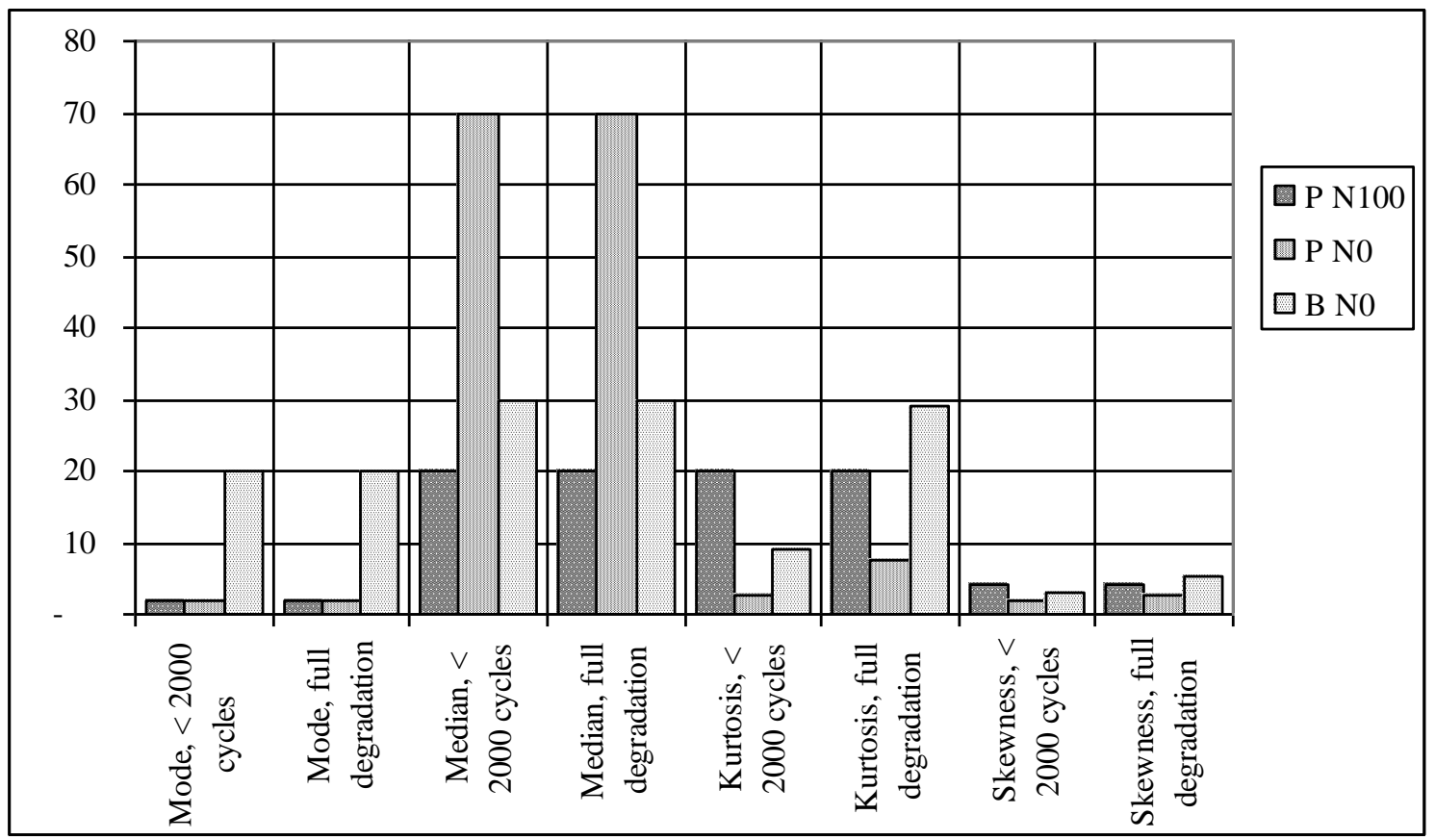

Fig. 3. Comparative parameters of distribution of durability cycles

Some of hemp durability distribution parameters such as mode and median do not change their values in cut experiment, but values of parameters which characterize deviation from normal distribution form for variants PNO and BNO decrease.

If samples tested till 2000 durability cycles, some samples extreme values are excluded, because they leave little impression on the product performance for the fact that the product performance more directly determines less resistant fiber resistance to repetitive deformations. As a result, durability distribution is closer to normal distribution, which is more predictable (Fig.3, Table 2). 


$\begin{array}{lccc}\text { Main statistic parameters of samples under examination till } & \text { 1000 cycles } \\ <\mathbf{1 0 0 0} \text { cycles } & & & \\ & \text { P N100 } & \text { P N0 } & \text { B N0 } \\ \text { Average } & 105,93 & 266,18 & 169,98 \\ \text { Mode } & 2 & 2 & 20 \\ \text { Median } & 20 & 70 & 30 \\ \text { Standard Deviation } & 217 & 365 & 284 \\ \text { Maximum } & 1000 & 1000 & 1000 \\ \text { Minimum } & 2 & 2 & 1 \\ \text { Range } & 998 & 998 & 999 \\ \text { Standard Error } & 22 & 36 & 28 \\ \text { Confidence Level (95,0\%) } & 42,52 & 71,46 & 55,63 \\ \text { Relative error } & 40 \% & 27 \% & 33 \% \\ \text { Kurtosis } & 8,56 & 0,13 & 3,29 \\ \text { Skewness } & 2,94 & 1,23 & 2,08 \\ \text { Cover full degradation of } & & & \mathbf{9 3 \%} \\ \text { fibers bundle } & \mathbf{9 7 \%} & \mathbf{8 7 \%} & \end{array}$

Table 3.

In the third table shown statistical characteristics, obtained by testing samples only up to 1000 tensile cycles, testifies that the distribution center parameter - arithmetic average slight decrease because maximal values shifts it as statistical parameter. The median remain on the same level, suggesting that the effect of little resistant fiber parts are perceived, are covered at least $85 \%$ of the fiber bundles durability.

From all graphs and tables are seen that from durability point of view, the best characteristics present fiber bundles of the variant PN0._Low characteristics of PN100 could be related to the fact that high doses of nitrogen weakens the cellulose cell walls, thereby reducing fibers ability to withstand repeated tensile deformations of this variety.

\section{Summary}

Hemp fiber samples verifications by durability tests useful to suspend by reaching a certain number of cycles. Probable 1000 cycles in quite aggressive regime, can be enough to effectively compare options/ lines/ varieties of the durability point of view, thereby reducing the test work time-consuming.

The obtained results show that PNO of the durability point of view is more desirable and is perspective for a local variety of hemp fiber development. However further studies on the effects of nitrogen doses on this line of hemp fiber durability and other mechanical properties required, whereas the cultivation of free nitrogen creates a range of agronomic and economic problems.

\section{References}

1. Robinson, R. The great book of hemp. The complete Guide to the Environmental, Commercial, and Medicinal Uses of the World's Most Extraordinary Plant. ISBN 0-89281-541-8. 1996, p. 247.

2. Norton, A. J. Murphy, Callum, R. Hill, A. S. Newman, G. The life cycle assessments of natural fiber insulation materials. Proc. of the 11th International Conference on Non-conventional Materials and Technologies (NOCMAT 2009), Bath, UK, 2009. 
3. Ministry of Agriculture of Latvia, Department of Agriculture and Rural Development. Data about flax and hemp industry in Latvia, 2010. Latvijas Industriālo kan̦epju asociācija (LIKA), http://lathemp.lv/wpcontent/uploads/2010/11/ZM_Lini_Kanepes_Konference.pdf. ZM dati.

4. Baltina I., Strazds G., Zamuska Z. Latvian Hemp Fiber Quality. Scientific Journal of RTU. 9. series., Materiālzinātne. - 4. vol., 2009, p. 9.-15.

5. Baltina I., Zamuska Z. Effects of Late Hemp Straw Harvesting on Fiber Quality. Scientific Journal of RTU. 9. series., Materiālzinātne. - 5. vol., 2010, p 194-198.

6. Freivalde L., Kukle S., Ulme A. Comparative Analysis of Hemp Fiber Durability. Scientific Journal of RTU. 9. series., Materiālzinātne. - 5. vol., 2010, p 134-138.

7. Freivalde L., Kukle S., Purina B., Stramkale V. Durability Properties of Hemp Fibres. In: Proceedings of the 5th International Textile Clothing and Design Conference Magic World of Textiles. ISSN 1847-7275, Dubrovnik, Croatia, 2010, p.83-86.

8. Stramkale V., Freivalde L., Kukle S. Analysis of the renewable fibres properties and uses in scale of Latvia// University of Ljubljana, Faculty of Natural Sciences and Engineering, Department of Textiles, ISBN 978961-6045-80-3, Ljubljana, Slovenia, 2010, p. 300. - 325.

\section{Kopsavilkums}

Katru gadu visā pasaulē arvien vairāk tiek novērota augoša tendence samazināt dažādu produktu ražošanu, kas satur neatjaunojamas izejvielas un aizstāt tās ar dabīgo šķiedru izejmateriāliem, kā tekstila, tā arī netekstila produktiem. Kaņepes ir viens no šādu izejvielu avotiem. Šajā referātā aplūkoti salīdzinošo pētījumu pārbaužu rezultāti vietējā genotipa "Pūriņi" un tirdzniecībā pieejamas, ES régistrētās rūpnieciskās šksirnes kaņepju "Bialobrzeskie" (Polija) šķiedras, kas audzētas Latvijā, Latgales Lauksaimniecības zinātniskajā centrā 2010.gadā. Pētījumi veikti kaņepju šķiedru ilgizturības īpašību noteikšanai un analīzei, testiem pakļaujot mazus primāro šķiedru kūlī̌sus. 